\title{
PELATIHAN PEMBUATAN LAPORAN KEUANGAN USAHA KECIL MIKRO DAN MENENGAH DI KECAMATAN CIPOCOK JAYA KOTA SERANG
}

\author{
Titis Nistia Sari ${ }^{1}$ \\ Dabella Yunia ${ }^{2 *}$ \\ Galih Fajar Muttaqin ${ }^{3}$ \\ 1,2,3 Universitas Sultan Ageng Tirtayasa, Serang, Indonesia \\ titisns@untirta.ac.id ${ }^{1)}$ \\ dabellayunia@untirta.ac.id ${ }^{*}$ ) \\ galih fajar muttaqin@untirta.ac.id ${ }^{3}$
}

Kata Kunci: [Usaha Mikro Kecil Menengah, Laporan Keuangan, Pengabdian Pada Masyarakat Mandiri]

Published by:

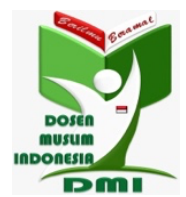

Copyright (C) 2021 The Author(s)

This article is licensed under CC BY 4.0 License (cc) $\mathrm{Br}$

Abstrak: Kegiatan pengabdian pada masyarakat berupa pendampingan dalam pembuatan laporan keuangan bagi usaha mikro dan kecil menengah di Kecamatan Cipocok Jaya. Laporan Keuangan merupakan catatan formal tentang keuangan dari suatu perusahaan. Ini adalah laporan tertulis yang mengukur kekuatan finansial, kinerja, dan likuiditas perusahaan. Selain itu, laporan keuangan juga mencerminkan dampak finansial dari transaksi bisnis. Dari hasil kegiatan pelatihan tersebut para anggota usaha mikro kecil dan menengah Kecamatan Cipocok Jaya mampu membuat neraca awal, membuat jurnal, memposting ke buku besar, menyusun laporan keuangan. Pelaksanaan pelatihan yang diberikan kepada anggota komunitas pedagang bakso di Kecamatan Cipocok Jaya sudah merupakan langkah tepat untuk memotivasi selera usaha masyarakat. 


\section{Pendahuluan}

Data UMKM di Provinsi Banten Tahun 2018 mencatat usaha mikro sebesar 6.495, usaha kecil sebesar 3.595, dan usaha menengah sebesar 222 yang berada di kota serang. Data tersebut menunjukkan perkembangan UMKM saat ini di Provinsi Banten khususnya di kota Tangerang (Lihat Tabel 1).

Tabel 1. Jumlah UMKM Menurut Kabupaten/Kota di Provinsi Banten Tahun 2018

\begin{tabular}{lcccccc}
\hline No & Kabupaten/Kota & $\begin{array}{c}\text { Usaha } \\
\text { Mikro }\end{array}$ & $\begin{array}{c}\text { Usaha } \\
\text { Kecil }\end{array}$ & $\begin{array}{c}\text { Usaha } \\
\text { Menengah }\end{array}$ & $\begin{array}{c}\text { Jumlah } \\
\text { UMKM }\end{array}$ & $\begin{array}{c}\% \\
\text { Mikro \& } \\
\text { Kecil }\end{array}$ \\
\hline 1 & Kabupaten Lebak & 49.498 & 825 & 15 & 50338 & 0 \\
2 & Kabupaten Tangerang & 41.155 & 0 & 0 & 41.155 & 0 \\
3 & Kabuten Serang & 22.667 & 3.958 & 294 & 28.999 & 0 \\
4 & Kota Tangerang & 11.079 & 533 & 34 & 11.746 & 0 \\
5 & Kota Cilegon & 6.446 & 100 & 0 & 6.546 & 0 \\
6 & Kota Serang & 6.495 & 3.595 & 222 & 10.321 & 0 \\
7 & Kota Tangerang Selatan & 7.094 & 2.488 & 0 & 3.582 & 0 \\
8 & Kabupaten Pandeglang & 900 & 100 & 2 & 1.002 & 0 \\
\hline
\end{tabular}

Sumber: https://statistik.bantenprov.go.id/

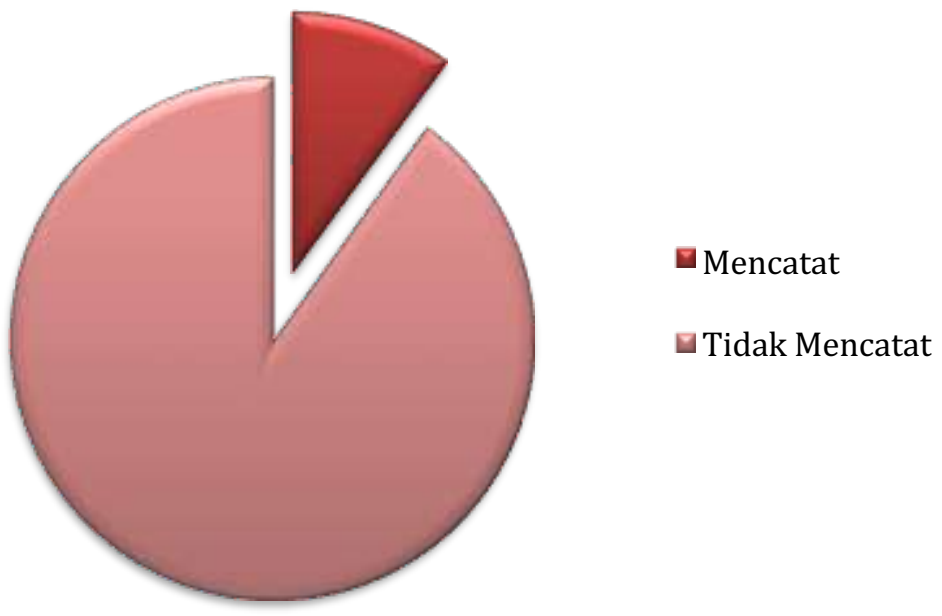

Sumber : Data diolah peneliti, 2021

Gambar 1. Hasil Survei Lapangan UMKM Penggunaan Laporan Keuangan

Berdasarkan survei pedagang bakso yang berada di kecamatan Cipocok Jaya, ratarata mereka tidak menggunakan pencatatan laporan keuangan dalam usahanya. Keuntungan yang di dapat tidak dapat dijelaskan dikarenakan tidak ada pencatatan keuntungan dalam usahanya. Sehingga sulit para pedagang bakso untuk mengetahui laba mereka secara benar. Terkadang untuk menjalankan usaha baksonya para pedagang bakso kerap mengalami kerugian, dimana mereka juga harus membayar karyawan yang membantu usaha baksonya. Hal tersebut di sebabkan karena keuangan yang masih tercampur antara usaha bakso dengan keuangan pribadi. Survei lainnya juga menujukkan bahwa sebagian kecil pedagang bakso kerap adanya ketidakmampuan dan ketidakmauan sumber daya atau pelaku pedagang bakso untuk menggunakan laporan keuangan. 
Sebuah usaha perlu adanya pengelolaan keuangan yang tepat, kegiatan tersebut biasanya meliputi perencanaan, pengoperasian, analisis kegiatan keuangan, serta kontrol, dan pengendalian keuangan, untuk itu diperlukan sebuah pelaporan keuangan yang benar dan akurat. Laporan Keuangan merupakan catatan formal tentang keuangan dari suatu perusahaan. Merupakan laporan tertulis yang mengukur kekuatan finansial, kinerja, dan likuiditas perusahaan. Selain itu, laporan keuangan juga mencerminkan dampak finansial dari transaksi bisnis. Bentuk laporan keuangan yang utama meliputi bentuk laporan laba- rugi, perubahan modal, neraca, dan laporan arus kas. Melalui keempat bentuk laporan keuangan tersebut dapat dianalisa kemajuan sebuah perusahaan, apakah perusahaan tersebut mengalami perkembangan yang pesat atau mengalami kebangkrutan.

Berdasarkan permasalahan tersebut, perlu diadakan kegiatan pelatihan bagi pelaku usaha bakso di Kecamatan Cipocok Jaya dalam hal mengelola keuangan secara sederhana. Program pelatihan yang ditawarkan berupa pelatihan meyusun laporan keuangan sederhana bagi pedagang bakso di Kecamatan Cipocok Jaya Kota Serang. Pelatihan ini ditujukan bagi pedagang bakso anggota Komunitas Pedagang Bakso Kecamatan Cipocok Jaya Kota Serang. Adanya pelatihan ini diharapkan pedagang bakso dapat mengetahui perkembangan perusahaan dan dapat memanfaatkan laporan keuangan guna mendukung kemajuan penjualan bakso mereka.

Banyak permasalahan di pedagang bakso yang berkaitan dengan aspek keuangan antara lain perkembangan usaha tidak signifikan, kinerja keuangan buruk, laba usaha sulit meningkat, ketidakmampuan dan ketidakmauan sumber daya untuk menggunakan akuntansi, dan lain-lain. Dari berbagai masalah tersebut, yang menjadi masalah utama adalah ketidakmampuan dan ketidakmauan sumber daya atau pelaku pedagang bakso untuk menggunakan laporan keuangan dalam kaitannya dengan pengelolaan dana yang mereka miliki. Sumber dana dan jenis penggunaan dana harus dicatat dengan tepat agar tidak terjadi penyelewengan dan ketidakberesan dalam kinerja keuangan perusahaan. Jadi, pelaporan keuangan sangat penting untuk digunakan dalam setiap kegiatan bisnis dalam pedagang bakso melakukan usahanya sehingga pedagang bakso dapat melakukan dan melalui berbagai tahapan dalam laporan keuangan dari input sampai output.

Kegiatan pengabdian pada masyarakat ini bertujuan untuk membekali kemampuan dan keterampilan pedagang bakso anggota komunitas bakso Kecamatan Cipocok Jaya agar dapat menggunakan laporan keuangan dengan mudah dalam kegiatan bisnisnya sehingga dapat meningkatkan kinerja keuangan usahanya. Tujuan pelatihan ini khususnya adalah dalam hal-hal sebagai berikut.

1. Peserta mampu dan terampil menjurnal dan memindahbukukan.

2. Peserta mampu dan terampil menyusun daftar saldo dan mencatat penyesuaian.

3. Peserta mampu dan terampil menyusun daftar saldo setelah penyesuaian.

4. Peserta mampu dan terampil menyusun laporan keuangan.

Kegiatan PPM ini diharapkan dapat memberi bekal kepada para pedagang bakso khususnya anggota komunitas bakso Kecamatan Cipocok Jaya sehingga dapat meningkatkan kinerja keuangan usaha mereka. Penguasaan laporan keuangan dengan mudah dan cepat akan memberikan manfaat bagi mereka dalam hal pengelolaan keuangan usahanya. Penyajian pelatihan pelaporan keuangan yang berdasarkan pada keadaan yang sebenarnya di dalam usaha pedagang bakso dan penggunaan pendekatan yang tepat akan menjadikan pelaku pedagang bakso memahami laporan keuangan secara 
mudah dan cepat. Pemahaman terhadap laporan keuangan diharapkan akan membantu pedagang bakso untuk mengelola sumber dana dan penggunaan secara cermat dan efisien sehingga pedagang bakso dapat berkembang lebih baik dan dapat meningkatkan perekonomian mereka.

\section{Metode Pelaksanaan}

Sebagaimana diuraikan dalam perumusan masalah, bahwa kondisi mitra perlu diperbaiki dan ditingkatkan kemampuannya sehingga dapat menambang keuntungan pedagang bakso dan nantinya diharapkan akan dapat meningkatkan kehidupan mereka. Khalayak sasaran kegiatan pendampingan pengelolaan keuangan dalam rangka menambah income pedagang bakso bagi anggota Komunitas padagang bakso Kecamatan Cipocok Jaya. Pelatihan diadakan di slah satu rumah dari anggota komunitas pedagang bakso yang berada di Kecamatan Cipocok Jaya degan jumlah khalayak sasaran yaitu 20 orang. Adapun yang menjadi instruktur dan narasumber dalam kegiatan ini adalah dosendosen FEB Universitas Sultan Ageng Tirtayasa Serang yang telah berpengalaman mengelola laporan keuangan sebuah bisnis.

Untuk dapat melaksanakan kegiatan ini dengan baik dan terarah maka metode kegiatan yang dilakukan adalah dirancang dengan sistematis dalam beberapa tahapan. Adapun tahapan kegiatan yang akan dilaksanakan adalah:

1. Ceramah bervariasi.

Metode ini dipilih untuk menyampaikan konsep-konsep yang penting untuk dimengerti dan dikuasai oleh peserta pelatihan. Penggunaan metode ini dengan pertimbangan bahwa metode ceramah yang dikombinasikan dengan gambargambar, animasi dan display dapat memberikan materi yang relatif banyak secara padat, cepat dan mudah. Materi yang diberikan meliputi: konsep pengelolaan keuangan, macam cara pelaporan keuangan, dan langkah-langkah pengelolaan keuangan.

2. Tutorial

Metode ini dipilih untuk menunjukkan suatu proses kerja yaitu tahap-tahap pengelolaan keuangan. Tutorial dilakukan oleh instruktur di hadapan peserta yang masing-masing mencatat sehingga peserta dapat mengamati secara langsung metode dan teknik pengelolaan keuangan yang sesuai dengan pencatatan keuangan pedagang bakso.

3. Latihan

Metode ini digunakan untuk memberikan tugas kepada peserta pendampingan untuk mempraktikkan pembuatan laporan keuangan.

4. Tahapan Monitoring dan Evaluasi

Kegiatan pelatihan dan evaluasi pasca tahapan pelaksanaan kegiatan pengabdian pada masyarakat mandiri.

\section{Hasil dan Pembahasan}

Pengabdian Pada Masyarakat Mandiri dalam Pelatihan Laporan Keuangan Sederhana Usaha Mikro Kecil dan Menengah di Kecamatan Cipocok ini telah dilaksanakan 
pada bulan Maret 2021. Adapun kegiatan-kegiatan yang telah dilakukan adalah sebagai berikut:

1. Identifikasi masalah dan hal-hal yang dibutuhkan oleh mitra pengabdian.

2. Sosialisasi akan diadakannya kegiatan Pengabdian Pada Masyarakat Mandiri pada UMKM di Kecematan Cipocok.

3. Peninjauan lokasi tempat UMKM di Kecamatan Cipocok.

4. Mempersiapkan kegiatan pelatihan laporan keuangan sederhana pada UMKM di Kecamatan Cipocok.

5. Melaksanakan kegiatan pelatihan pengabdian Mandiri:

a. Pelatihan Pembuatan laporan Keuangan Sederhana: Dabella Yunia, SE., M.SA., Ak., CPA

b. Praktek Pembuatan laporan Keuangan dengan Excel: Titis Nistia Sari, S.ST., ME

Proses pelatihan dan praktik berlangsung efektif dan penuh antusias dengan adanya pelatihan serta aktifnya peserta di tandai dengan adanya tanya jawab serta diskusi selama pelatihan berlangsung.

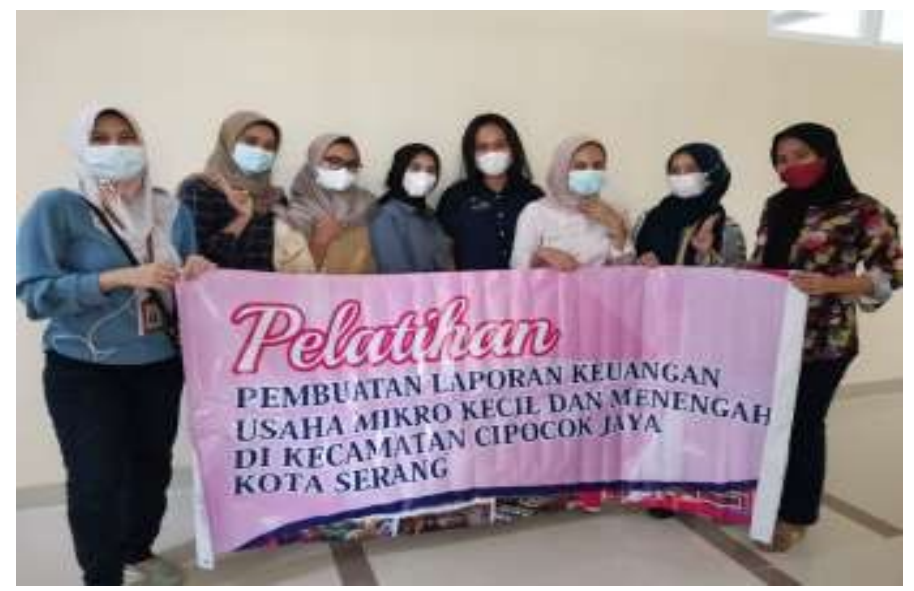

Gambar 2. Peserta Pelatihan

Pelatihan laporan keuangan sederhana akan berdampak pada bisnis umkm di kecamatan Cipocok kedepannya. Adanya pelatihan ini diharapkan dapat menambah dan meningkatkan nilai ekonomi yang lebih baik dibandingkan sebelumnya yang sempat mengalami kendala terhadap persoalan pencatatan keuangan.

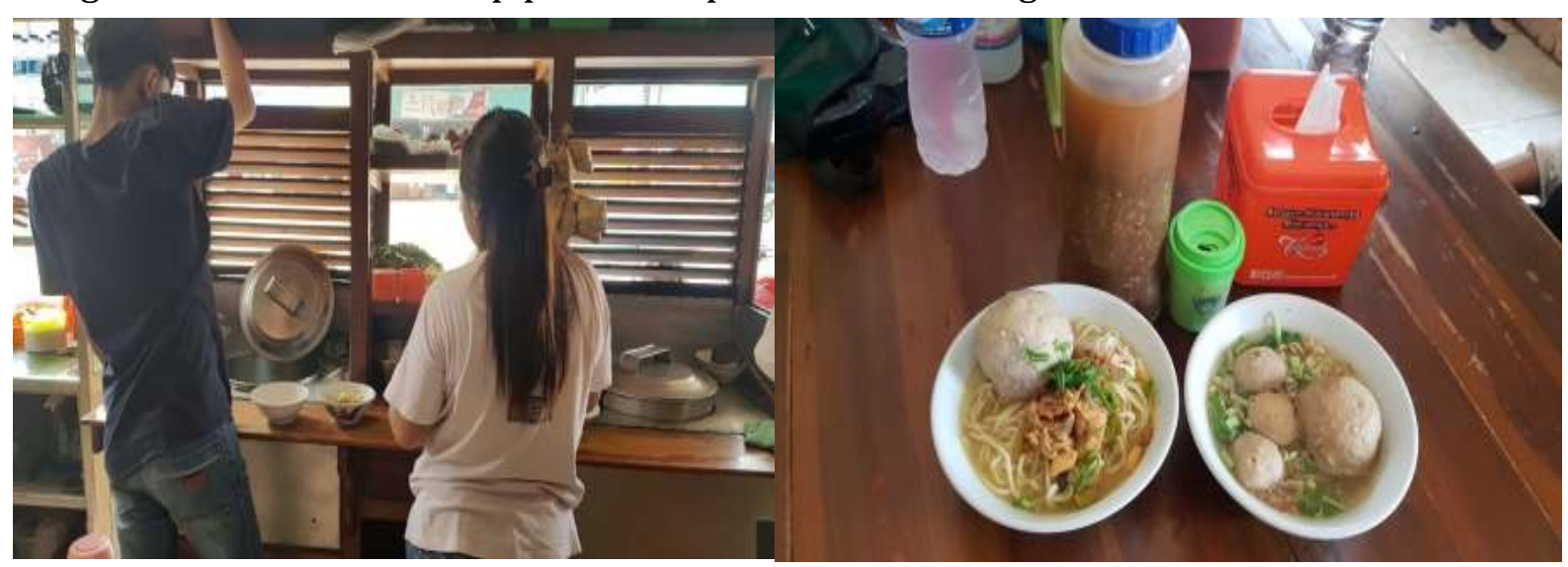

Gambar 3. UMKM Warung Bakso 
Keberhasilan dari pelaksanaan program pengabdian pada masyarakat mandiri ini dilihat dari dua tolok ukur sebagai berikut:

1. Respons positif peserta pelatihan

Respon positif yang diberikan melalui tanggapan dan umpan balik peserta selama pelatihan dengan pengamatan langsung. Dengan cara memberikan kesempatan kesempatan kepada peserta untuk berdiskusi dan tanya jawab.

2. Meningkatnya kemampuan keterampilan peserta setelah mendapat pelatihan

Kemampuan keterampilan peserta pelatihan dalam mempraktikan pembuatan laporan keuangan sederhana dengan buku kas dan kertas kerja laporan keuangan.

\section{Kesimpulan}

Pengabdian pada masyarakat mandiri Pelatihan Laporan Keuangan Sederhana UMKM di Kecamtan Cipocok telah dapat dijalankan dengan baik dan tanpa halangan yang berarti. Hasil pendampingan mitra pengabdian mandiri sudah dapat menggunakan buku kas dan kertas kerja laporan keuangan sederhana. Dengan kerjasama tim pengabdian mandiri yang baik dan peran serta aktif dari pelatihan dalam kegiatan pengabdian ini maka semuanya telah berjalan sesuai yang diharapkan dan harapannya dapat memberikan manfaat bagi mitra UMKM di Kecamatan Cipocok.

\section{Ucapan Terimakasih}

Ucapan terima kasih atas terselenggaranya kegiatan pengabdian kepada masysrakat kami sampaikan kepada pihak-pihak yang telah bekerja sama yaitu Fakultas Ekonomi dan Bisnis dan Lembaga Penelitian dan Pengabdian Kepada Masyarakat Universitas Sultan Ageng Tirtayasa.

\section{Referensi}

Dinas Koperasi dan UKM. 2018. Jumlah Usaha Mikro, Kecil dan Menengah menurut Kabupaten/Kota di Provinsi Banten Tahun2018. https://statistik.bantenprov.go.id/ekonomi/koperasi

DRPM. 2018. Panduan Penelitian dan Pengabdian kepada Masyarakat Edisi XII. Direktorat Riset dan Pengabdian Masyarakat. Direktorat Jenderal Penguatan Risetdan Pengembangan Kemenristekdikti.

Permenristekdikti Nomor 42 Tahun 2016 Pengukuran dan Penetapan Tingkat Kesiapterapan Teknologi (Technology Readiness Level).

Renstra LPPM. 2020. Rencana Strategis Lembaga Penelitian dan Pengabdian kepada Masyarakat Universitas Sultan Ageng Tirtayasa.

Renstra Untirta. 2019. Peraturan Rektor Universitas Sultan Ageng Tirtayasa Nomor 13 Tahun 2019. Rencana Strategis Renstra Universitas Sultan Ageng Tirtayasa Tahun 2019-2023. 